\title{
Rahvapiibel slaavi rahvameditsiini tavade selgitajana
}

\author{
Valeria Kolosova
}

\begin{abstract}
Teesid: Artikkel näitab, kuidas taimede tunnused muutuvad slaavi rahvakultuuris oluliseks faktoriks ja taimede rahvameditsiinis kasutamise valiku aluseks. Tunnus tagab ühe või teise piiblitegelase kohta käivate uskumuste seostamise haigussümptomitega. Teise vahendaja - emakeele - roll pole rahvakultuuri eri koodide seostamisel sugugi vähem tähtis. Taime nimetus seostub edaspidi sõnade ja reaaliatega, moodustades teiseseid assotsiatsioone. Võib öelda, et vähemalt kaudselt vaadeldakse haigust rahvakultuuris mitte üksnes anomaalse seisundina, vaid ka olukorrana, mis on lähedane esmaloomise mütoloogilisele ajale, ja haige paigutub mütoloogilisse ruumi, kus ta kasutab ravimina taimi, mis seostuvad kristlikust mütoloogiast tuntud isikutega. Esmaloomise müütilise aja ja ruumi olukord kordub iga uue patsiendi ravimisel alati uuesti.
\end{abstract}

Märksõnad: etnobotaanika, folkloor, rahvameditsiin, rahvapiibel, slaavi dialektoloogia

Taimed moodustavad slaavi rahvameditsiinis kasutatavatest ravivahenditest märgatava osa. Nende valiku aluseks on teatud printsiibid. Üks neist on signatura rerum, st ettekujutus sellest, et taim näitab oma välimusega, millise haiguse puhul tuleb seda kasutada. Kuid taimede murdenimetuste korpus, samuti etioloogiline pärimus viitab taime ja haiguse ahelas veel ühe vahepealse lüli - teatud piiblitegelase - olemasolule.

Haige inimese ja tema rituaalse kaitsja vastastikustes suhetes mängib üks või teine taim väga tähtsat rolli oma iseloomulike tunnuste tõttu, mis meenutavad üht või teist piiblitegelast, täpsemalt episoodi tema elust. Näiteks nimetused, mille koostisse kuulub sõna pea, antakse tavaliselt taimedele, millel on sfäärilised osad (lilleõisik, seemned jne): nimetust адамова голова (aadamapea) kannab Siberis põldjumikas (Centaurea scabiosa L. ), Permis sinine mesiohakas (Echinops ritro L.) (Annenkov 1876: 90-91), Ukrainas nurm-ogaputk (Eryngium campestre L.) (Bulašov 1909: 349). Vrd: "Et lapsed ei kardaks, tuleb neile aadamapea padja alla panna" (Konovalova 2000: 18). Fütonüüm märgib 


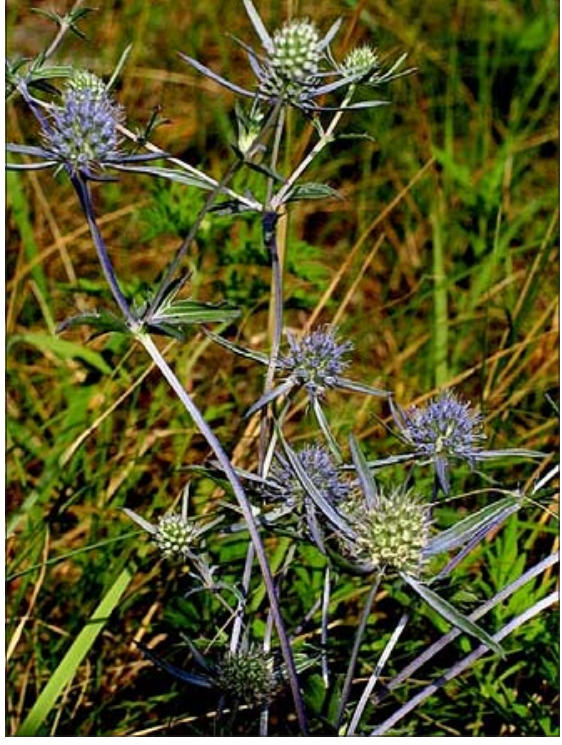

Illustratsioon 1. Nurm-ogaputk (Eryngium campestre L.). http://www.trifoly.ru/ green/str_w_3/stranisi/2.html

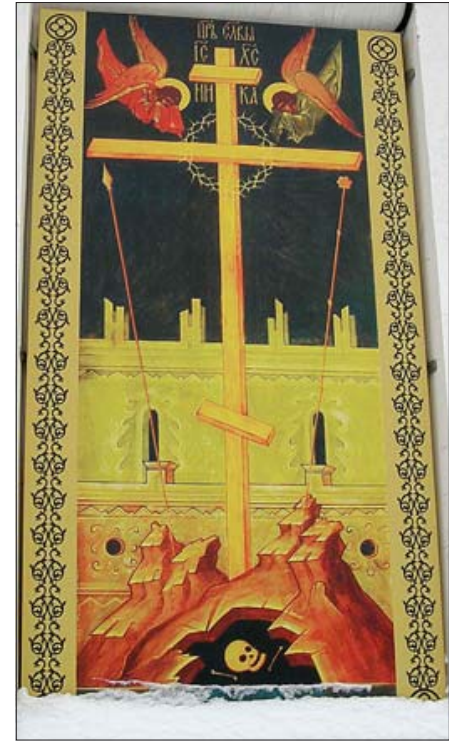

Illustratsioon 2. Peeter-Pauli kiriku välissein Permis. S. Koroljova foto.

siin omamoodi kokkusurutult motiivi Aadama peast, mis oli paigutatud Kolgata mäe alla, sellepärast paigutatakse ka sama nime kandev taim padja alla. Kuid fütonüümid, mille koostises sisaldub pea, kuuluvad ka taimedele, mida kasutati peavalu ravimiseks. Pole imeks panna, et need kaks taimerühma sageli ristuvad: "Kõrge ja peenike, kaks-kolm heledat peakest on tal, aadamapea aitab haige pea puhul, näe, vaata, helesinised torkivad pallikesed" (Rodionova 2002: 38).

\section{Raviomaduste seos pühakutega}

Lekseem pea seostub peale Aadama ka püha Johannese nimega. See seos põhineb piiblisüžeel Ristija Johannese pea mahalöömisest. Kurski kubermangus nimetatakse ivanova golovaks ('ivani [johannese, jaani] pea') suureõielist kellukat (Campanula persicifolia) (Annenkov 1876: 90-91), Uuralis kuulub nimetus ivan golovastõi ('suurpea ivan') soo-nõianõgesele (Stachys palustris): “Ivan golovastõi kasvab märja koha peal, tal on õisik justnagu pea" (Sverdlovski oblasti Berjozovski rajoon) (Konovalova 2000: 94-95); vrd ka valkjas mesiohakas (Echinops sphaerocephalus L.) (Annenkov 1876: 398), Poolas św. Jana glowa (püha jani pea) tähniline aarum (Arum maculatum), Ivanowa holowa valkjas 
mesiohakas (Echinops sphaerocephalus) (Morawski 1884: 40). Nagu näha, esineb fütonüümi esimeses pooles seisva kuuluvusasesõna (possessiivadjektiivi) allikana pühak, kellel raiuti pea otsast. ${ }^{1}$

Sama printsiipi võib täheldada ka егорьево (егорьевское, георгиево) копье ('jegori [jüri] oda') tüüpi nimetuste puhul - seda nime kannavad taimed, millel on pikad või teravad osad, ogad. Fütonüümid, mis kajastavad kokkusurutud vormis püha Jüri võitlust lohega, on Vologda kubermangus егорово (егорьево) копье (вероника ложная, sarnlev mailane (Veronica spuria L.); вероника длиннолистная, pikalehine mailane (Veronica longifolia L.). Nimetust егорьево копье kannab Tomski kubermangus üheksavägine (коровяк медвежье yхо, Verbascum thapsus L.); Jenissei ja Irkutski kubermangus ning Sverdlovski oblastis aaskurereha (герань луговая, Geranium pratense L.); Irkutski kubermangus mets-kurereha (герань лесная, Geranium sylvaticum L.); IdaSiberis, Siberis ja Irkutskis nurmnelk (гвоздика полевая, Dianthus deltoides L.). KeskUuralites on егорьевское копье nime all tuntud aas-kurereha (герань луговая) ja Arhangelski kubermangus harilik sinilatv ( синюха голубая, Polemonium caeruleum L.) (SRNG 8: 317). Teisest küljest põhineb taime ravimina kasutamine samuti tunnusel: näiteks Uuralis nimetatakse jegori odaks sakiliste kroonlehtedega nurmnelki või oda meenutavate rohkete harali vartega aas-kurereha. Nende taimedega ravitakse voolmeid kõhus: "jegori odal on tõelised teravad ogad, ongi oda", "jegori oda korjatakse aasalt, seda juuakse pistete vastu kõhus" (Konovalova 2000: 61, 80). Tomski oblastis Šegarka rajoonis kasutatakse seda "kõhuvalu vastu, haavade läbipesemiseks” (Arjanova 2006:132).

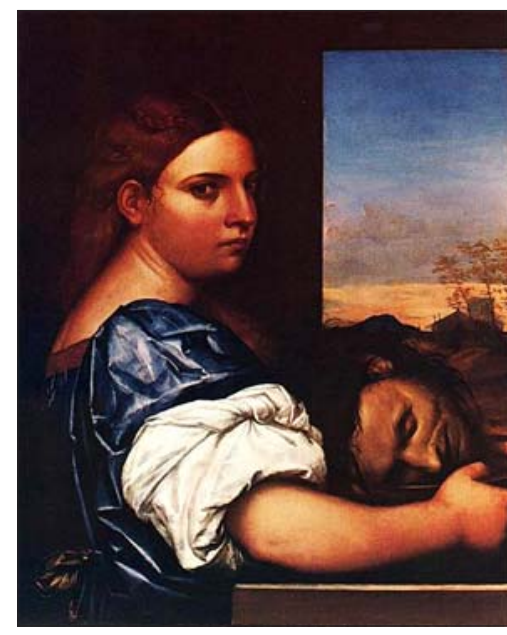

Illustratsioon 3. Sebastiano del Piombo. Heroodiase tütar. 1510. http://www.patriarchia.ru/db/text/ 140955.html

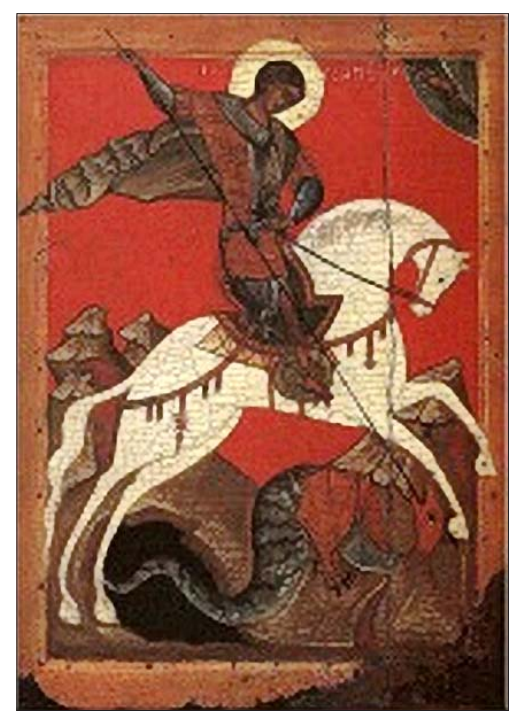

Illustratsioon 4. Püha Jüri. Album Novgorodi ikoonikunst, 14. saj. http://fotki.yandex.ru/users/ nadezhdmorozova/view/ 112169 ? page $=0$ 
Jegorirohtude juhtum on huvitav selle poolest, et fütonüümi ja folkloorse süžee sidet toetab ka ikonograafiline traditsioon - ikoonidel kujutatakse lohetapjat püha Jürit, oda käes. Niimoodi annab taime vorm, täpsemalt tema osade vorm, aluse seostada episoode pühaku elust haigussümptomitega.

\section{Jaanipäeva võim taimedes}

Kõigil slaavlastel on olemas uskumus, et jaanipäeval korjatud taimedel on eriline jõud, sellepärast on see päev ravimtaimede korjamiseks sobivate kalendaarsete tähtpäevade seas põhiline, see kajastub ka taimede nimetustes. Bulgaarias korjatakse hobumadarat (Galium verum L., blg еньовка) jaanipäeval, sellest punutakse jaanipäevapärg, millest neiud ja noored naised läbi poevad. Sellele omistatakse võime peletada eemale maod, näkid ja mitmesugused haigused (Marinov 2003: 104). Jaanipäeva ja selle kaudu püha Johannese järgi on nimetatud ka (paljude leksikaalsete variantidega) apteegikummel (Matricaria chamomilla L. ) - blg енево цвете('jaanilill'), енево пиленце('jaanitibu'); hobumadar (Galium verum, енювче, иванковка); harilik raudrohi (Achillea millefolium L, енюво биле) jt (Ahtarov 1939: 37, 87, 207, 398).

Üks jaani- ehk Ristija Johannese päevaga seotud tähtis taim on puju. Seda kasutasid sel päeval kõik slaavlased, kusjuures üsna sarnasel moel ja eesmärkidel. Kõigepealt teravneb vajadus kaitsta ennast ebapuhta jõu eest. Jaanipäeva eel pärja jaoks lilli ja taimi korjates lisasid Poltaava kubermangus tüdrukud ja lapsed sinna puju, et kaitsta ennast nõidade rünnaku eest, puju kanti ka kaenla all (Sementovski, A. 1845: 108; Sementovski, K. 1845: 227; Arandarenko 1849: 216). Väike-Vene aladel korjasid tüdrukud ja lapsed lisaks lilledele samuti puju "kui rohtu, mis kaitseb tumedate jõudude kõigi mõjude eest, ja seda hoitakse kogu püha jooksul kaenla all" (Kupala 1861: 21). Ukrainas "lähevad tüdrukud hommikul põllule ja metsa korjama lilli ja taimi, nendest punutakse endale kupalapärjad, pärjas peab olema ka puju, peale selle kannavad nad kogu päeva puju kaenla all; see on kaitsevahend näkineidude ja nõidade eest” (Markevitš 1860: 10). Pole välistatud, et valgevene laulus, mida sel ööl lauldakse, kajastub komme kaitsta ka kariloomi:

[---] А стары дзед короукау,

Як першы раз у поле гонюць,

А их вербай паганяюць,

Святым зельем подкурауць,

Боже-дреукай да и мятай
Vanataat lehmi, viib esimest korda karjamaale, neid pajuvitsaga ${ }^{2}$ kannustab, suitsutab püha taimega, sidrunpuju ja piparmündiga. 
Illustratsioon 5. Puju (Artemisia L.).

http://geobotany.narod.ru/plants/sa-15.jpg

Oodanud ära, millal lõkke äärde tuleb tule järele kõige vanem vanaeit (ведзьма), aeti ta pujuga nüpeldades minema (Dmitrijev 1869: 223-227). Arvatavasti on uskumus, et puju mõjub nõidadele (kes oletuste kohaselt võtsid lehmadelt piima ära), ka järgmise tegevuse aluseks: "Jaanipäeval korjatud pujust tehtud tõmmisega pestakse lehmi, et nad annaksid rohkem piima" (Afanasjev 1995 (2): 574-575).

Puju raviomadusi selgitab ka poola rahvapärimus: ristija Johannese mahalõigatud pea kukkus puju sisse, sellepärast aitab puju

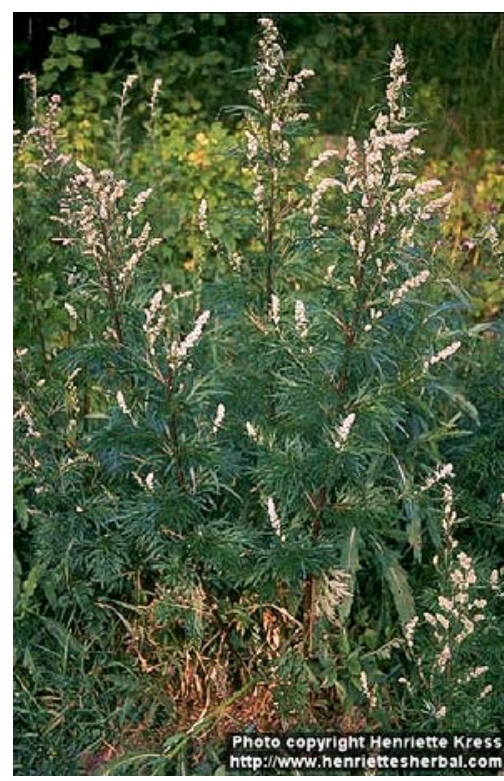
lõikehaavade puhul (Morawski 1884: 14). Harilik puju (Artemisia vulgaris L.) sai poola keeles nimetuse swietojańskie ziele ('püha jaanirohi'), tšehhi keeles kutsutakse seda pas sv. Jana ('püha jani vöö'), "sest ebausklikud inimesed kaitsevad ennast jaanipäeval selle rohuga" ja "sellepärast, et seda tuleb korjata jaanipäeval, muidu ei ole tal väge" (Annenkov 1876: 50, Machek 1954: 249).

\section{Kalendritähtpäevad taimesümboolikas}

Taimesümboolika formeerumisel on väga oluline ka värvus, milles muu hulgas kajastub ettekujutusi ka raviomadustest. Taimedel, mille värv meenutab verd, on nime tüves sageli sõna veri, ja arvatakse, et see taim suudab peatada verevoolu. Samas võib selline tunnus assotsieeruda ka Ristija Johannese valatud verega. Suur hulk fütonüüme, mis tulenevad tüvest veri, kuuluvad lihtnaistepunale (Hypericum perforatum L.): Umanis uljas veri (молодецкая кровь), Kaluuga kubermangus seitsme venna veri (семнбратная кровь) (Annenkov 1876: 172); valgevenelastel verirohi (крываўнік, крывавец ) (Gantšarõk 1927: 205), ukrainlastel ivani veri jne (Ivan krov, krov śv. Ivana, krovavec, krovavnyk) (Makowiecki 1936: 185-186), tšehhidel krevniček, krvaunik (Machek 1954: 149), poolakatel krewiec, krew św Jana (püha jani veri) (Henslowa 1976: 231). See fütonüümiline jada tuleneb suve lõpus taime lehtedele ilmuvatest punastest laikudest, lisaks on punane naistepuna tõmmis, samuti purustatud lehtede mahl. Etioloogilise pärimuse kohaselt olevat siis, kui timukas viis Ristija Jo- 


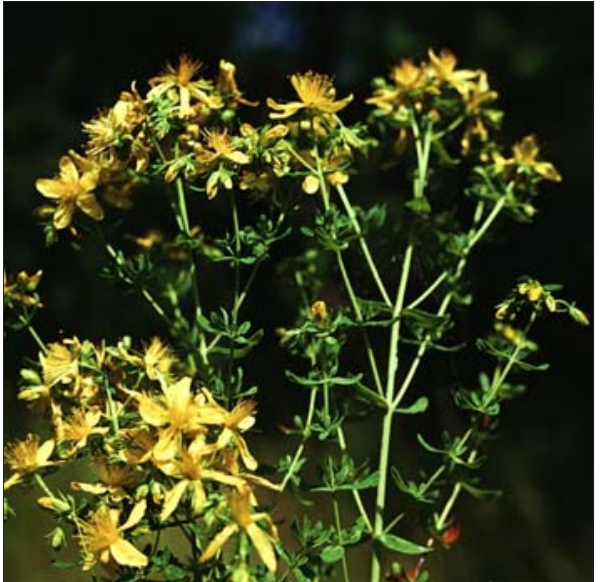

Illustratsioon 6. Liht-naistepuna (Hypericum perforatum L.). http://dic.academic.rul pictures/enc_medicine/0272597233.jpg

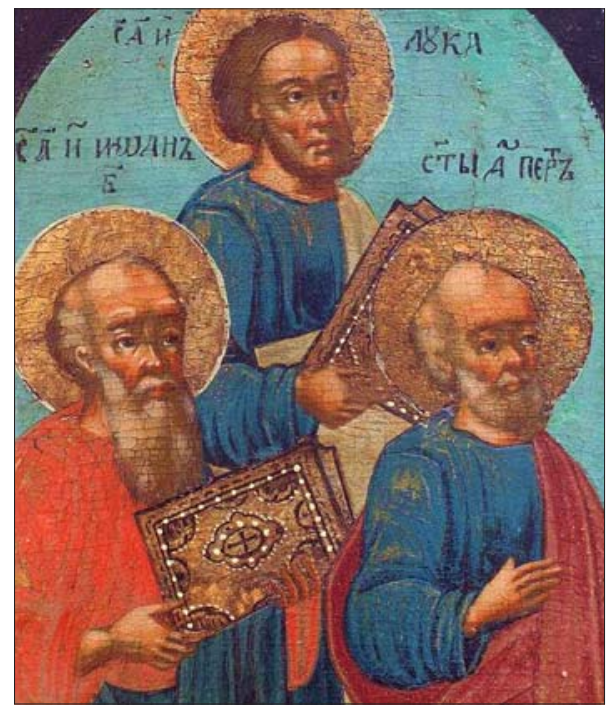

Illustratsioon 7. Apostlid Johannes, Luukas ja Peetrus. Fragment apostliku auastme ikonostaasilt. Venemaa, 18. sajandi lõpp. http://www.cirota.ru/forum/ message_mt.php?id=3283253 hannese pead Heroodese lossi, kukkunud mõni tilk verd maha. Sinna, kuhu veri tilkus, kasvas rohi, mis imes vere endasse - see oli naistepuna (Kuznetsova \& Reznikova 1992: 86). See legend selgitab naistepuna päritolu, soovitades samal ajal selle kasutamist rahvameditsiinis: Taga-Karpaatias joodi kandilise naistepuna (Hypericum quadrangulum L. ) tõmmist verevalumite, samuti verise kõhulahtisuse ("kui kõhust tuleb verd") korral. Lihtnaistepuna (Hypericum perforatum $L$.) kasutamine on seotud vereköhimisega, samuti verikusesusega (Kubanis); seda kasutati ka haavade kinnikasvatamiseks (Toren 1996: 67), Bulgaarias aga verehaiguste korral (SK 1993: 178-179, 180, 187).

Naistepuna õitsemisaeg, aga ka korjamine jaanipäeval kajastub reas nimetustes: venelastel святоивановская трава (püha ivani rohi), ukrainlastel $с в я-$ тоянское зелье (püha jaani rohi) (Annenkov 1876: 172) ја іванок (ivanilill) (Grintšenko 1958: 195), valgevenelastel сьвятаянкі, сьвентаянскае зельля, св. Ивана зельле (pühajaan, püha jaani rohi, püha ivani rohi) (Gantšarõk 1927: 205), serbohorvaatidel иватчица, иванова трава, трава св. Ивана (jaanirohi, püha ivani rohi) (Tšaikanovits 1985: 35), bulgaarlastel яневички (jaanililled) (Ahtarov 1939: 184), serbohorvaatidel ivanjčica, ivanjica, ivanje zelje, trava svetog Ivana (ivanirohi, püha ivani rohi), sloveenidel roža svetega Janeža

(Šulek 1879: 525), vana-tšehhi keeles Svateho Jana kořenie (püha jani juured), Sv. Jana bylina, poola keeles świętego Jana korzenie (püha jani juured) (Machek 1954: 148). Ühtselt on märgitud naistepuna nimetuseks herba Sancti Petri; see võib tuleneda asjaolust, et peetripäeva eraldab jaanipäevast, millega see 
taim sagedamini seostub, vaid mõni päev. Peale selle võis oma osa etendada ka see, et epilepsia, mille puhul naistepuna kasutati, võidi maarohuraamatutes nimetada nii püha Jaani haiguseks (morbus Sancti Joanis) kui ka püha Peetri haiguseks (morbus Sancti Petri) (Henslowa 1976: 230-231).

Poola nimetus Świętego Piotra korzenie (püha piotri juured) üheksalehelise hammasjuure (зубянка девятилистная, Dentaria enneaphylla) kohta seletub asjaoluga, et “tal on palju juuri, igaüks on otsast ära hammustatud, nagu oleks püha Peetrus seda hammustanud"; vastavalt pärimusele kasutatakse taime tõmmist hambavalu korral loputamiseks (Kolberg 1874: 130). Puju ja takja juuri nimetati Poolas Kielce piirkonnas püha peetruse juurteks (korzenia św. Piotra) ja nendega raviti haigeid hambaid (Szot-Radziszewska 2005: 120). Peetrileht (Succica pratensis) sai oma poolakeelse nimetuse 1ysina ś. Piotra (püha piotri lauk) nähtavasti läikivate ja paksude lehtede tõttu (Spólnik 1990: 116) nagu teada, kujutatakse Peetrust ikoonidel eaka mehena.

Kõige levinum Peetruse nimega seotud sõnaühend taimenimedes on peetri rist. Seda võidakse kasutada mitmete taimede puhul: Tambovi kubermangus magus hundihammas (Astragalus glycyphyllus L.) ja südame-emajuur (Gentiana cruciata L.), Vjatka kubermangus ja Altais alpi elulõng (Atragene alpina L.), Vladimiri kubermangus mitmeõieline kuutõverohi (Convallaria polygonatum L. ), Nižni Novgorodi kubermangus kevadine kurelääts (Orobus vernus L.), Voroneži kubermangus harilik sealõuarohi (Scrophularia nodosa L.), aga mõnel pool ka harilik käopäkk (Lathraea squamaria L.) (Annenkov 1876: 57-58, 106, 154, 186, 236, 322, 392, 396), Uuralis mets-seahernes (Lathyrus silvestris) (Konovalova 2000: 156), Permi kubermangus kõdu-koralljuur (Corallorhiza trifida Chatel) (Toren 1996: 70). See ühend on tuntud ka teistes keeltes: ukraina keeles петров крест (Poltaava kubermangus), петрів хрест ja serbo-horvaadi keeles Petrov kerst (harilik käopäkk Lathraea squamaria L.) (Annenkov 1876: 186, 375; Bulasev 1909: 349). Enamasti antakse sellised nimetused ristikujuliselt hargnevate juurtega (mis on eriti aktuaalne pea alaspidi risti löödud Peetruse puhul) või ristikujuliselt paiknevate lehtedega taimedele (Tšasovnikova 2003: 28-29, 56).

Märkigem, et Edela-Ukrainas nimetatakse harilikku käopäkka (петров крест чешуйчатый, Lathraea squamaria L.) юрьив хрэст (jüri rist), sest seal hakkab see kasvama palju varem ja seetõttu seostatakse seda teise pühaku nimega. Vastavalt nimetusele on seda taime

Illustratsioon 8. Harilik käopäkk (Lathraea squamaria L.). http://www.ecol.ural-ecol.uu.ru/krkn/images/lathrea_!.gif

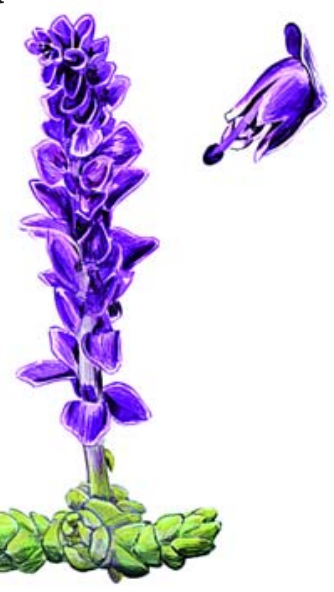


kohalikus pärimuses kasutatud jüripäeval, mis on karja esimese rituaalse väljalaskmise päev - seda korjatakse, hakitakse peeneks ja lisatakse lehmade toidule, et ära hoida haigusi ja kehva piimaandi aasta jooksul (EU Tšernovits 99).

Vähem on levinud kastega pesemise komme sel päeval, kuigi ka see kajastus fütonüümides. Uuralite eri piirkondades nimetati jüripäeva kasteks erinevaid esimesi kevadisi taimi:

Nimetus on seotud kombega koguda jüripäeval taimede pealt kastet ning pühkida sellega silmi ja teisi haigeid kehaosi, aga ka pritsida koduloomi [---]. Aja käigus on kaste kogumise komme ununenud, aga nimi on kinnistunud kevadisele rohule, seejärel läinud edasi konkreetsetele taimedele, enamasti mahlastele kevadistele söödataimedele (Konovalova 2000: 214).

Bulgaaria rahvafütonüümides kajastusid lisaks isikutega seotud kalendritähtpäevadele ka lihavõtted: harilikku mailast (Veronica officinalis, blg великденче) korjatakse ainult lihavõtte ajal, see pannakse veepotti ning pestakse sellega tüdrukuid ja lapsi, et need oleksid terve aasta terved (Marinov 2003: 104); mitmed iminõgesesordid on saanud nime великденче, великдень (lihavõttelill, hõlmine iminõges Lamium amplexicaule), жълто великденче (kollane lihevõttelill, koldnõges Lamium galeobdolon), червено великденче (punane lihavõttelill, verev iminõges Lamium purpureum) (Ahtarov 1939: 37, 193).

Lõunaslaavi pärimuses on oluline veel üks kristlik tegelane: püha Vitus. Tema nimega on seotud serbiakeelsed nimetused видовска трава, видовчица, видовица, видовка (viituserohi, põld-varsapõlv Anagallis arvensis L.); see taim on täies õies viidipäeva eel (Špis-Ćulum 1995: 413). Kuivõrd slaavi keeltes as-

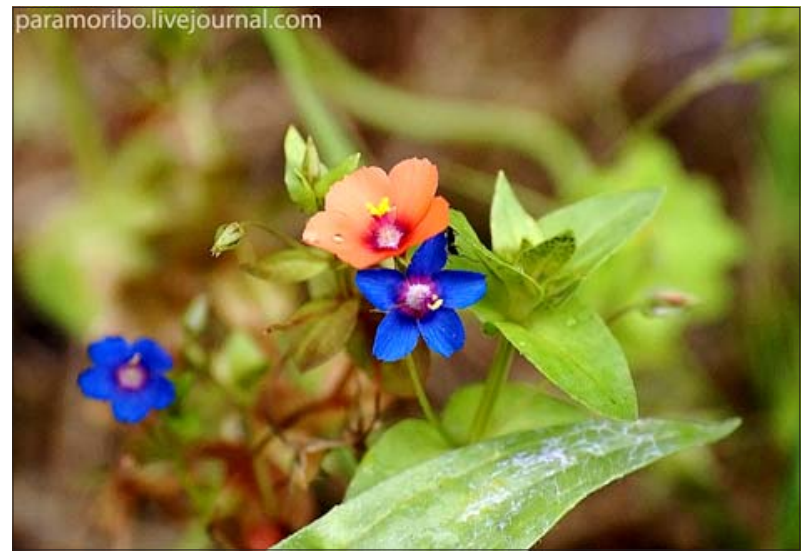

Illustratsioon 9. Põld-varsapõlv (Anagallis arvensis L.). http://img-fotki.yandex.ru/get/51/evelinalina.2/0_c106_149ca09b_XL 
sotsieerub püha Vituse nimi tegusõnaga видети'nägema, mõistma, läbi nägema', pesti selle tõmmisega pimedate ja vaegnägijate silmi, aga neiud ja noormehed ennustasid selle kohal, et näha oma tulevase abikaasa nägu. Seda taime pandi ka veetassi ja jäeti hommikuni seisma, et enne päikesetõusu selle veega silmi pesta. Huvitav on märkida, et видова трава (viidirohi), mille rituaalne korjamine oli ajastatud viidipäevaks (Видовден), arvati Serbias ja Bulgaaria lääneosas olevat isane ja emane: "esimesel on sinised, teisel roosad õied" (Petrovitš 1992: 278, tsiteeritud Ivanova 2002: 160 kaudu; Popov 2004: 134).

\section{Jumalaema ja tema käsi}

Piiblimütoloogia tegelastest enim on taimi seotud nähtavasti jumalaemaga. Nii oli Ohridis makedooniakeelse nimetuse рака од Пречиста (jumalaema käsi) all tuntud jeeriku roos (veerpallirohi, Anastatica hierochuntica L.), millel on iseloomulik rusikasse surutud käe kuju. Ohridi türklased arvasid, et see taim tekkis Naatsaretis, kus neitsi Maarja sünnitas Kristuse ja toetus käega maapinnale. Nii türklannad kui ka makedoonlannad panid taime vette, ja kui see hakkas rusikast avanevate sõrmede kombel võrseid ajama, anti sünnitajale seda vett juua (Džordževitš 1958: 126). ${ }^{3}$ Vrd ka tänapäevast ülestähendust Bulgaariast Plovdivi piirkonnast (taime nimi märkimata): raske sünnituse korral pannakse veega künasse ööseks viie õiega rohtu ръчичка на св. Богородица

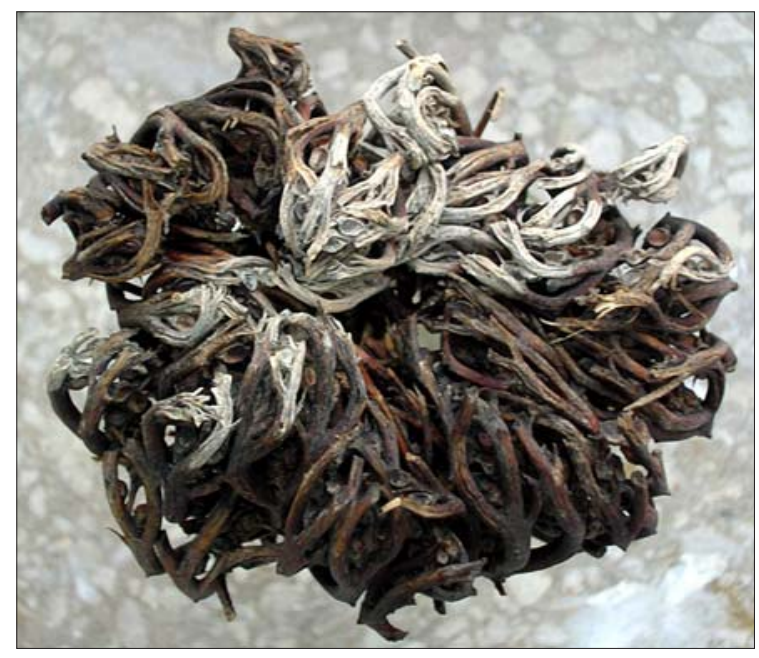

Illustratsioon 10. Jeeriku roos (Anastatica hierochuntica L.). http://molbiol.ru/forums/uploads/a001/b006/post-5389-1155552644.jpg 


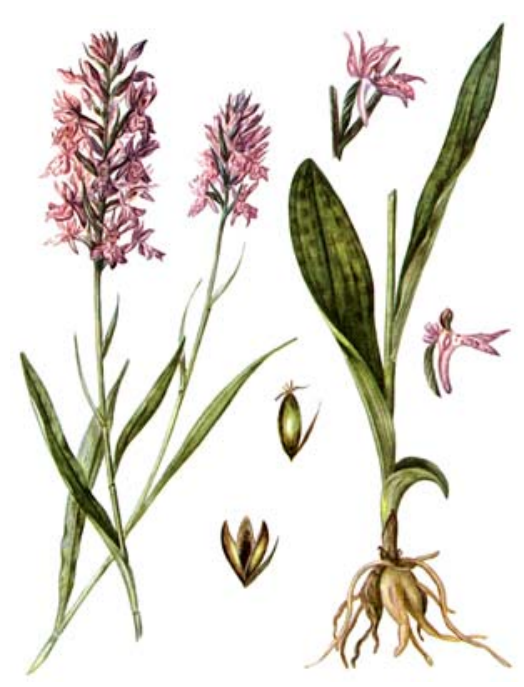

Illustratsioon 11. Kuradi sõrmkäpp (Orchis maculata L.). http://da.kirsoft.com.ru/images/lp0089.jpg

(sõnasõnalt 'jumalaema käsi'). Hommikul sünnitaja joob seda. Öösel avanevad õied vees; usutakse, et nii kergelt nagu avanevad taime õied, sama kergelt ja kiirelt avaneb ka sünnitaja üsk (Kableškova 202: 95-96; Sedakova 2007: 179).

Käpaliste perekonna taimedel on selliste nimetuste esinemine tingitud teisest põhjusest, nimelt mugulate sõrmjast vormist: vene keeles Priargunskis пятипалечник, соломонидина ручка ${ }^{4}$ (viissõrmik, solomoniida käsi, kahkjaspunane sõrmkäpp Orchis latifolia L.);

Voroneži kubermangus пятипалечная трава, Arguni krais пятипалешник, serbohorvaadi keeles krstoruka, krstova ruka, isusova ruka (kristuse käsi, jeesuse käsi) (Šulek 1879: 537), poola keeles dloń chrystusowa (kristuse peopesa, kuradi sõrmkäpp Orchis maculata L.); valgevene keeles божья ручка(jumala käsi, kuradi sõrmkäpp Orchis mascula L., Magiljovi kubermang) (Annenkov 1876: 233-234); valgevene keeles далонка, bulgaaria keeles рьчица (käekene, jumalakäpp) (SD 2: 596). Inimese peopesa meenutav juurte vorm on aidanud kaasa teatud fütonüümide moodustumisele, kuid mõjutanud ka taimele maagiliste omaduste omistamist.

Juure vormist on tingitud etioloogilised tekstid, mis selgitavad ebatavalise taime päritolu, aga nimetus seostas ta maagia selliste vormidega, millesse oli kaasatud ka inimese käsi tegelikult: Valgevenes soovitati armsama äravõlumiseks "pesta oma käsi halli käpa (Orchis militaris L., valgevene keeles dalonka Najświentszej Matki, jumalaema peopesa) käekujulise juure peal hoitud veiniga, pärast seda pidi võlutavale neidisele käe andmine äratama temas armutunded" (Wereńko 1896: 116).

Punased täpid naistepuna lehtedel, millest me rääkisime juba seoses Ristija Johannesega, kutsuvad slaavi maailma teises osas esile teistsuguseid assotsiatsioone: näiteks serblaste muistendis seostatakse naistepuna seda omadust jumalaema menstruaalverega, taim ise on aga serbia keeles saanud nimetuse богородичина трава, богородица, богородичица, госпино цвеће, госпина трава, госпино зеље (jumalaema rohi, jumalaema, jumalarohi, jumalahein; Tšajkanovitš 1985: 35, 259; Sofritš 1990: 13). Hariliku kirburohu (Polygonum persicaria $L$.) lehtedel on samuti tumepunased täpid, neid lehti kasutas jumalaema uskumuse kohaselt kuuriiete ajal, ja Serbia ühes paikkonnas kannab taim 
nime трава мајке божје(jumalaema rohi) (Špis-Džulum 1995: 425). Slovaki ja tšehhi muistendites seletatakse jumalaema menstruaalverega tumedaid plekke teiste taimede lehtedel - vrd slovaki zelina Panny Marie (kare kirburohi Polygonum lapathifolium L.) ja vanas tšehhi keeles Svate Mar̆i košile (püha maarja särk, kirburohi Polygonum L.). See seletab ka kirburohu kasutamist emakaverejooksude korral ja menstruaaltsükli reguleerimiseks. Harilik kirburohi (Polygonum persicaria L.) kuulub jumalaema rohtude hulka ka poola pärimuses, siin kannab see nime Matki Boskiej ziele: "kui inimesed rohtu korjasid, näitas jumalaema taime sõrmega, sellest puudutusest jäi järele jälg kolmnurkne pruunikas plekike igal lehel" (Budziszewska 1993: 88-89).

On veel üks fütonüümi rolli täitev püsiv sõnaühend - сон богородицы. Eelkõige on nimetuse “Сон Богородицы” (jumalaema unenägu) all tuntud apokriivatekst, milles räägitakse jumalaema prohvetlikust unenäost, mis ennustas tema poja tulevikku. See apokriiva levis käsikirjalises vormis ja seda kasutati amuletina. Sõnaühend jumalaema unenägu oli fütonüümina kasutusel Tšernigivi kubermangus metsülase (Anemone sylvestris L.) kohta, ülase teised vormid, aga ka karukellad, said nimeks $\mathrm{COH,} \mathrm{COH}^{-}$ траваjne (uni, unerohi; Annenkov 1876: 34-35). Aas-karukella (Pulsatilla pratensis) ja laialehelist karukella (Pulsatilla latifolia) nimetati vene keeles samuti сон-трава (uni-rohi, valgevene keeles сон лугавы, сон-трава) taime paindes kuju tõttu, kus õis puudutab peaaegu maad (Punase

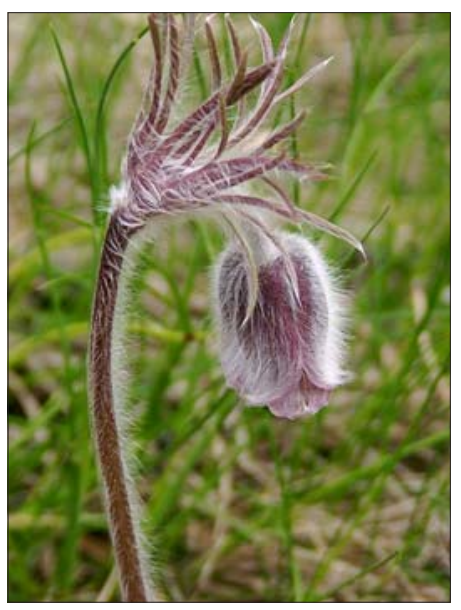

Illustratsioon 12. Aas-karukell (Pulsatilla pratensis L.).

http://www.plantarium.ru/dat/ img/18342_325e0eac.jpg 1987: 180, 182).

Ukraina pärimusjutus põhjendatakse taime välimust järgmiselt:

У всех цветов есть мать; не имеет матери только сон-трава; у него злая мачеха; ежегодно она выгоняет его из земли ранее, чем покажутся какие-либо другие цветочки. “Сон, сон, ступай вон, - говорит она, - бо вже вси цвиткы зацвилы, тилько тебе нема”, и послушный сон вылазит из земли, оглядывается по сторонам и не видит ни одного товарища. Свесит тогда она свою умную головку на бок, как сиротка, и дремлет до тех пор, пока не появятся его товарищи: козельцы (Anemone ranunculoides), медунки (Pulmonaria), фиалки и др.

Kõigil lilledel on ema, ainult uni-rohul ei ole ema, temal on kuri võõrasema, kes igal aastal ajab teda maa seest välja enne, kui teised lilled 
ennast näitavad. "Uni, uni, mine välja," ütleb ta, "kõik lilled juba õitsevad, ainult sind ei ole," ja kuulekas uni-rohi poebki maa seest välja, vaatab ümberringi ega näe ühtki seltsilist. Langetab siis oma targa peakese küljele nagu orvukene ja tukub seni, kuni ilmuvad seltsilised kollased ülased (Anemone ranunculoides), kopsurohi (Pulmonaria), kannikesed jt (Sumtsov 1889: 115).

Teise pärimuse kohaselt "nägi jahimees ükskord, kuidas karu tõmbas selle taime juure välja ja hakkas seda lakkuma, aga pärast jäi purjakile. Jahimees hakkas ka seda juurt lakkuma ning peagi tuli talle uni peale" (Annenkov 1876: 34). Lille kuju soodustas olemasoleva sõnaühendi kinnistumist taime nimes.

Kuivõrd taimenimes esineb sõna $\mathrm{COH}$ (uni), oli sellega seotud ka taimede kasutusvaldkond. Näiteks Permi oblasti Kunguri maakonnas ennustati haige tervist järgmiselt: taime сон пресвятой богородицы (pühima jumalaema unenägu, kõrge kukekannus Delphinium elatum L.) anti "tõmmisena rasketele haigetele, kes olid juba tervenemislootuse kaotanud. [---] Kui haige pärast selle ravimi võtmist uinub ja magab rahulikult, saab ta terveks, vastasel juhul sureb" (Annenkov 1876: 34-35, 398). Permikomi ringkonnas pandi nimetuste сон-трава, богородицына трава (uni-rohi, jumalaema rohi) all tuntud aas-karukell (Pulsatilla pratensis L.) lapsele voodisse, kui laps halvasti magas (SRG 2006: 318-319). Samal otstarbel kasutati ka nõmm-liivateed (Thymus serpyllum L.), mida nimetati ka сон богородицы, богородицкий сон, богородский сон (jumalaema uni) (SRG 2006: 299-300). Teisalt pandi tervenemise lootuses paberilehele kirjutatud apokriivatekst haigele padja alla. Niimoodi kandus religioosselt tekstilt taimele üle mitte üksnes nimetus, vaid (osaliselt) ka funktsioonid.

Vene rahvapärimuses on jumalaemaga seotud taimede seas ilmselt esikohal roomav tüümian ehk nõmm-liivatee (Thymus serpyllum L.). Paljudes vene murretes on sellele taimele antud jumalaema nimi: богородицкая трава (Arhangelski oblasti Vilegodski rajoonis, Vologda oblasti Harovski rajoonis), богородицына травка (Arhangelski oblasti Pinega rajoonis), богородная травка (Vologda oblasti Njuksenitsa rajoonis), богородская трава (травка) (Vologda oblasti Verhovažje rajoonis) (SGRS 1: 127, 129, 134), богородская трава (koht märkimata), богородицына трава(Aunuse kubermangus), богородичная травка (Astrahani ja Katerõnoslavi kubermangus) (Annenkov 1876: 354), богородка (Sverdlovski oblasti Taborõ rajoonis), богородная трава (Kemerovo oblasti Jaškino rajoonis) (SRNG 3: 53); богородицкая трава (Donskoje) (Brõsina \& Kudrjašova 2003: 272), богородская трава (Kesk-Uural) (Konovalova 2000: 37), богородица, богородная трава, богородская трава (Obi piirkond) (Arjanova 2007: 143). Arvatavasti omandas taim sellise staatuse oma lõhna pärast, mis kajastub ka nimedes земляной ладан, земной ладан (maaviiruk) (Arjanova 


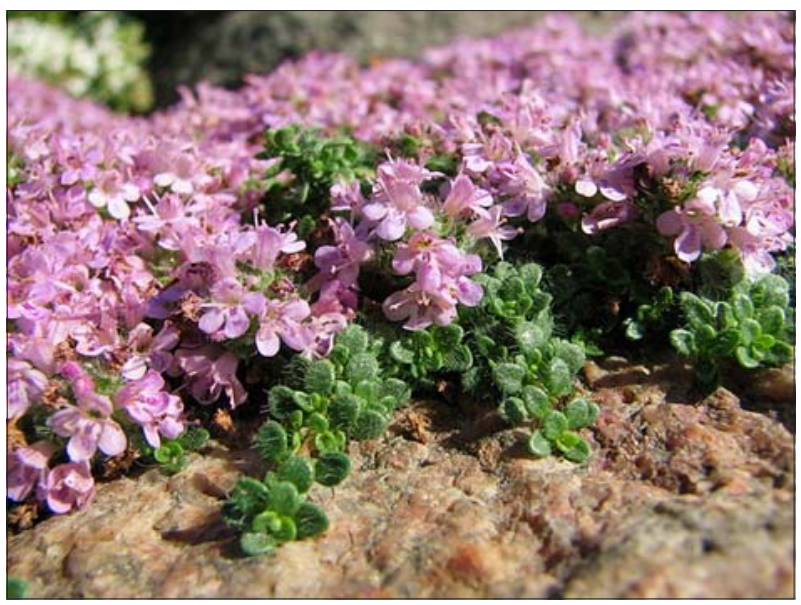

Illustratsioon 13. Roomav tü̈̈mian ehk nõmm-liivatee (Thymus serpyllum L.). http://totalrating.ru/i/10/b_9724timyan.jpg

2007: 143). Sama tunnus - lõhn - tingis ka rohu kasutamise kristlikes kombetalitustes: kui keegi peres suri, kitkuti seda ja pühitseti kirikus ning toodi pärast koju (Kemerovo oblasti Jaja rajoonis); sellega täideti kadunukese padi (Tomski oblasti Tomski rajoonis) (Arjanova 2007: 144); vrd: “jumalaema rohi lõhnab kirikus väga hästi, isake süütab selle põlema, midagi helget, kõigi tõbede vastu, joomarluse vastu - kõik teeb inimeses õilsamaks" (Sverdlovski oblasti Kamenski rajoon) (Konovalova 2000: 37-38).

Tüümiani pruugitakse rahvameditsiinis ohtrasti. Seda kasutatakse peavalu vastu (Arhangelski oblasti Vilegodski rajoonis), maja suitsutamiseks (Vologda oblasti Njuksenitsa rajoonis) (SGRS 1: 129). Permi kubermangus kasutati seda ka külmetuse ja südamehaiguste vastu, samuti laste unetuse puhul; Siberis köha puhul; Tobolski kubermangus palaviku tõrjeks; Kostroma kubermangus tõmmisena peavalu, palaviku ja köha ravimiseks. Sellega raviti ka langetõbe, haavu, hambavalu. Irkutski oblastis tehti nõmm-liivateest mähiseid paistetuse korral ja kasutati seda "krampide vastu" (Toren 1996: 63). Väga lai on nõmm-liivatee kasutusala Uuralites: "Jumalaema rohi on arvatavasti iseenesest kasulik, aitab kõige vastu, laste kärsituse vastu, naistehädade korral" (Sverdlovski oblasti Šalja rajoon); "kui inimene sureb, pannakse seda, kaetakse; kui lehm poegis, siis suitsutati teda selle rohuga; närvide rahustamiseks juuakse (Sverdlovski oblasti Kamenski rajoon); seda taime kasutati ka "ülemiste hingamisteede raviks, rahustava vahendina unetuse korral, valuvaigistina radikuliidi, vigastuste, paistetuste puhul, ussirohuna ja sapivaevuste korral, [---] teadvusekaotuse, mäluhäirete, meningiidi jne korral" (Konovalova 2000: 37). Ka Obi ääres on see taim oluline: sellega ravitakse peavalu, külme- 
tust ja südamehaigusi, sellega suitsutatakse tõbede tõrjumiseks inimesi ja karja (Kemerovo oblasti Jaja rajoonis), seda pannakse haige koha peale (Kemerovo oblasti Tšebula rajoonis); juuakse köha, soole- ja neeruhaiguste korral (Kemerovo oblasti Jašinski rajoonis) (Arjanova 2007: 143-145).

Taimedest väärib mainimist veel soovõhk (Calla palustris), mida Uuralites teatakse nimetuse богородицына помощь (jumalaema abi) all: "Rahvameditsiinis kasutatakse seda peaaegu universaalse vahendina: valuvaigistina, lahtistina, reuma- ja põletikuvastase ravimina jne"; "jumalaema abi ravib kõige paremini, see on lihtsalt kasulik" (Sverdlovski oblasti Asbesti rajoon); a это богородицына помощь тожо хоть от чё помогат (aga see jumalaema abi aitab mistahes haiguse vastu, Sverdlovski oblasti Polevskoi rajoon) (Konovalova 2000: 36). Et jumalaema käsitletakse naise ja emana, aga ka naiste kaitsja ja eestkostjana, on täheldatav temaga seotud taimede ahas kasutusala: harilikku kassikäppa (богородицына трава, Antennaria dioica L., Tveri kubermang ) kasutatakse "valgevooluse vastu ja korrapäratu kuupuhastuse puhul" (Annenkov 1876: 37-38); Uuralites kasutatakse трава-мария või марийка('таarjarohi') nimelist metsarohtu "aurutamiseks ja joomiseks naistetusa puhul" (Sverdlovski oblasti Šadrinski rajoon) (Konovalova 2000: 193-194).

Veel mõni näide samast reast: väikeste siniste õitega tugevasti lõhnav roomav akakapsas (Ajuga reptans L. ) on Kesk-Uuralites tuntud kui богородичник, богородка, богородицына трава, богородичное зелье (jumalaema-rohi), rahvameditsiinis kasutatakse seda "universaalse tugevdava vahendina mitmete haiguste korral", rögalahtistina (Sverdlovski oblasti Severouralski rajoon), unetuse vastase vahendina (Sverdlovski oblasti Tugulõmi rajoon). Akakapsaga suitsutati ka tube, selle kimpe riputati tuppa, tehti nn unepatju (Sverdlovski oblasti Serovi rajoon), seda kasutati rahustina (Sverdlovski oblasti Põšma rajoon) (Konovalova 2000: 36-37). Katerõnoslavi (Jekaterinoslavi) kubermangus kandis see taim nime богородичник, aga selle lähedast vormi Ajuga Chamaepitys L. nimetati богородичное зелье(Annenkov 1876: 18-19). Uuralites kasutatakse paljude peenikeste kõverate kõrtega sirelilillade kerakujuliste õitega metstaime богородицына помощь mesinduses putukatõrjeks, aga ka rahvameditsiinis: "Jumalaema abi on raviks, kõige paremini ravib" (Sverdlovski oblasti Suhhoi Logi rajoon); "me paneme ta ikooni alla, et kaitseks" (Sverdlovski oblasti Prigorodnõi rajoon); дедушко богородицыной помочью ульи подкуриват, пчелы тоды не улетают (taadid suitsutavad jumalaema abiga tarusid, mesilased ei lenda siis minema, Sverdlovski oblasti Mihhailovski rajoon) (Konovalova 2000: 38).

Venemaa põhjapiirkondades kannab tüümian ka nime боговы слёзки (jumalapisarad), богова слёзка(jumalapisar) (Vologda kubermangu Nikolski, Sokoli, Ustjužna ja Harovski rajoon): “Jumalapisaral on varreke ja sellel väikesed te- 
rakesed, nagu pisarad" (Harovski rajoon); "Jumalapisarad - sellised erepunased õiekesed, väikesed” (Nikolski rajoon). Selle sõnaühendiga assotsieerub poega taga nuttev jumalaema, selle tõttu on selle nimega taime kasutatud ikoonide kaunistamiseks ja raviotstarbel: “Jumalapisarad kasvavad tihedasti, sellised varrekesed, aga neil vaevu-vaevu kõik väreleb, justkui peakesed tema peal. Sellest punuti ikoonide juurde pärgi”(Sokoli rajoon); "Jumalapisarad on hõbedased, südamekesed pisi-pisikesed, justkui elus oleks rohi. Kogu talve seisab, ei närbu" (Sokoli rajoon); "Jumalapisarad, see on selline nagu mistahes seemned, peenike, kasvab põldudel, justkui terake, läheb ravimiseks” (Vologda oblasti Ust-Kubinski rajoon) (SGRS 1: 127).

Sama süžee kajastub ka tüümiani nimetuses плакун(halaja, nutja): "Plakun on sama, mis jumalaema rohi. Jumala ema nuttis Issandat leinates, sellest hakkaski nuturohi kasvama" (Arhangelski kubermangu Pinega rajoon) (SGRS 1: 129). Tõenäoliselt just sellel uskumisel tekkis tekst "Стиха о книге Голубиной“" [Luuletus Tuvi raamatust]:

Почему Плакун трава всем травам мати?

Мать Пречистая Богородица

По своем по сыне по возлюбленнем,

По своем по сыне слезно плакала,

А роняла слезы на землю пречистыя,

А от тех от слез от пречистыих

Зарождалася Плакун трава травам мати

Miks on nuturohi kõigi taimede ema?

Kõige puhtam jumalaema

oma poega armastatut,

poega taga nuttis härdasti,

poetas maale pisara õnnistatu,

aga nendest pisaratest puhastest

tärkas nuturohi, kõigi taimede ema (Fedotov 1991: 128).

Maloarhangelski kreisist üles kirjutatud uskumuse kohaselt tärkab nuturohi pisaratest ja võib kasvada vagade peremeeste õuel (Jakusin 1844: 42). Tšehhi slzički Panny Marie (neitsi Maarja pisarad, metsnelk, Dianthus sylvestris L.) on samuti valgete täpikestega, arvatakse, et see taim hoiab Maarja pisarate jälgi ja paistab silma võime poolest ravida haigeid silmi, kui lille kevadel esimest korda nähes pühkida sellega silmi, suudelda ja visata üle pea. Tegevust saadavad sõnad: Marie Panny slzički, aby mne nebolely očički (Neitsi Maarja pisarad, ärgu mul silmakesed valutagu) (Zibrt 1896: 569, tsiteeritud Usatševa 2000: 267 kaudu; Velmezova 2004: 62, 90). 


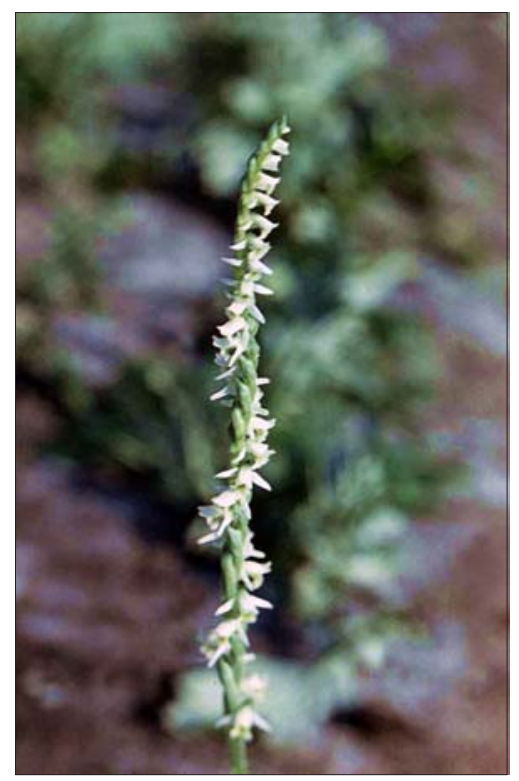

Illustratsioon 14. Hiline keerdkäpp (Spiranthes spiralis (L.) Chevall).

http://flower.onego.ru/orchid/ena_3020.jpg

Poola Izy Matki Boskiej (jumalaema pisarad, hiline keerdkäpp Spiranthes spiralis) on Tadeusz Severini sõnul "Neitsi Maarja taevassevõtmise suurpüha (15. august) puhul pattude lunastamist taotlevate palverändurite unistuste objekt Kalwaria Zebrzydowskas". Legendi kohaselt kasvasid need lilled jumalaema pisaratest, mis kukkusid tema näolt maapinnale. Jumalaema muldasängitamise päeval (13. august) pistavad need taimed oma nina rohu seest välja, et vaadata muldasängitamisele kantavat jumalaema. Antud juhul pole fütonüüm seotud üksnes etioloogilise süžeega, vaid ka rakendusega: "need pisarad peavad ravima igasugust valu". Peale selle arvati, et need lilled võisid ka kasvada "üksnes selle tee kõrval olevatel aasadel, mida mööda lähevad palverändurid jumalaema puust kujuga kirstu järel”, ja kõik katsed kasvatada neid aias jäävad tulutuks (Seweryn 1946: 307). Samasse rühma kuulub ka ülemsorbikeelne swjateje Marine sylzy (püha Maarja pisarad, fuksia Fuchsia) (Wjela 1896: 140).

Lõpuks kajastub slaavi etnobotaanikas ja rahvameditsiinis ka selline piiblimütoloogiline episood nagu Kristuse ristipiinad. Naistepuna päritolust, millest oli eespool juba pikalt juttu, eksisteerib veel üks legend: naistepuna kasvas Kristuse ristilöömise risti alla ja sai oma tervendava jõu Kristuse verest (Mandelštam 1882: 316). Liht-naistepunal (Hypericum perforatum L.) on palju кров- (veri)-tüvega fütonüüme: ukraina keeles biža krovća, boža krivća, Xristova krovća, krov Is. Xrysta (jumalaveri, kristuse veri) (Makowiecki 1936: 185-186), poola keeles krew Chrystusa (kristuse veri) (Henslowa 1976: 231). Harilikku kirburohtu (Polygonum persicaria L.) nimetatakse Serbias голготска трава (kolgata rohi), "sest legendi kohaselt kasvas see Kolgatale, kust levis omakorda kogu maailma". Seda nimetatakse христова крв, sest usutakse, et "ristilöödud Kristuse veri tilkus taime peale, millel on seetõttu täpilised lehed" (ŠpisĆulum 1995: 425).

Volgogradi kubermangust pärit etioloogilises legendis räägitakse, et käokinga lehed on korrapäratu kujuga selle tõttu, et neid on rebestanud oda, millega juudid torkisid nende lehtede alla peitunud Kristust. Vastavalt nimele joodi käokinga tõmmist pistete puhul küljes ja rinnus. Moonutatult kajastub 
see süžee fütonüümides укрыт, хранитель, христопродавка, христово копье (kaitstu, hoidja, kristuse müüja, kristuse oda; Vologda kubermang), aga ka прикрыт(kaetud, Siber), большой прикрыт (suur katja, Krasnojarski krai Dauuria rajoon) (Annenkov 1876: 7). Sama uskumus oli tuntud ka Permi kubermangus, nagu ka fütonüümid христов прикрыт, христопокрой, прикрыт, хранитель, kusjuures "arstlikuks kasutamiseks võetakse ainult rääbakas taim, siledat peetakse aga surmavaks" (Annenkov 1876: 387). Samalaadsed fütonüümid võivad tähistada ka teisi taimi: христа прикрыт, христов прикрыт(siberi elulõng Atragene sibirica) "kasutatakse laialt rahvameditsiinis ainevahetushäirete, reumatismi ja külmetushaiguste korral" (Konovalova 2000: 200). Põldjumikat (Centaurea scabiosa L.) kasutati Permi kubermangus nimetuse христосовы ребра (kristuse ribid) all seljavalude korral (Annenkov 1876: 91).

Sageli omistatakse Kristuse nimi taimedele nende raviomaduste tõttu; трава иисуса христа (jeesus kristuse rohi, punane tolmpea Cephalanthera rubra Rich.) - “jeesus kristuse rohi peatab verejooksu, temaga võib igasuguseid haigusi lausuda", usuti Uuralites. Samalaadseid nimetusi võisid taimele anda ka muud kasulikud omadused, näiteks hinnaline söödataim suur parthein (Glyceria aquatica Wahlb.) sai nime трава иисуса христа: "Rohtu nimetatakse jeesus kristuse rohuks sellepärast, et alati on, millega toita" (Sverdlovski oblasti Tugulõmi rajoon) (Konovalova 2000: 193). Kortslehe (Alchemilla vulgaris $L$.) nimetuse христова роса (kristuse kaste) tekitas arvatavasti kontaminatsioon väljendiga божья роса: "tal on lehekesed sellised säbrulise moega, aga keskel on piisako-

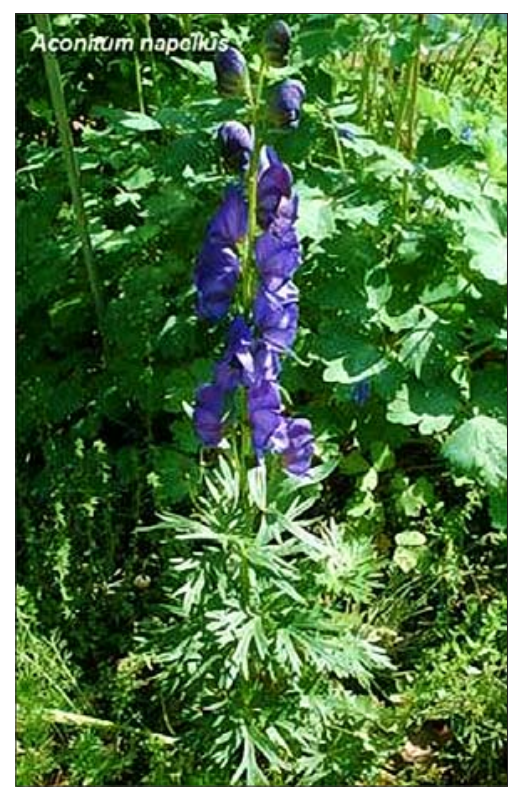

Illustratsioon 15. Sinine käoking (Aconitum napellus L.).

http://herbalogya.ru/library/img/ aconitum-napellus.jpg

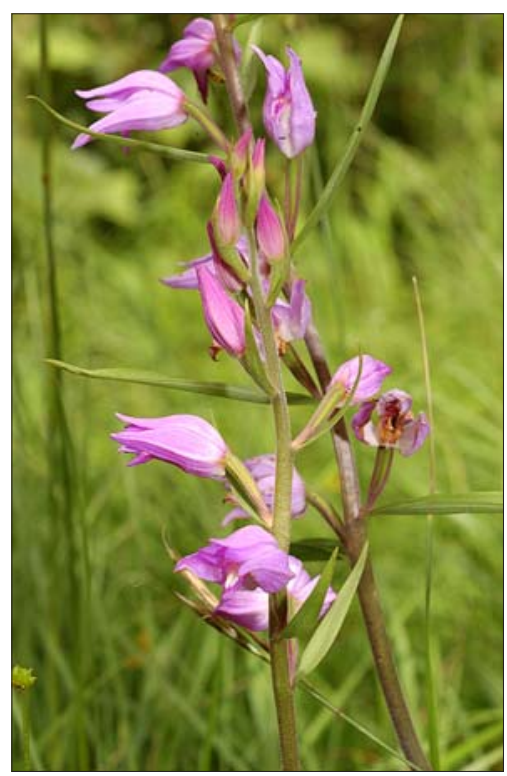

Illustratsioon 16. Punane tolmpea (Cephalanthera rubra (L.) Rich.). http://avflower.com/articles/1/ cephalanthera_rubra2.jpg 


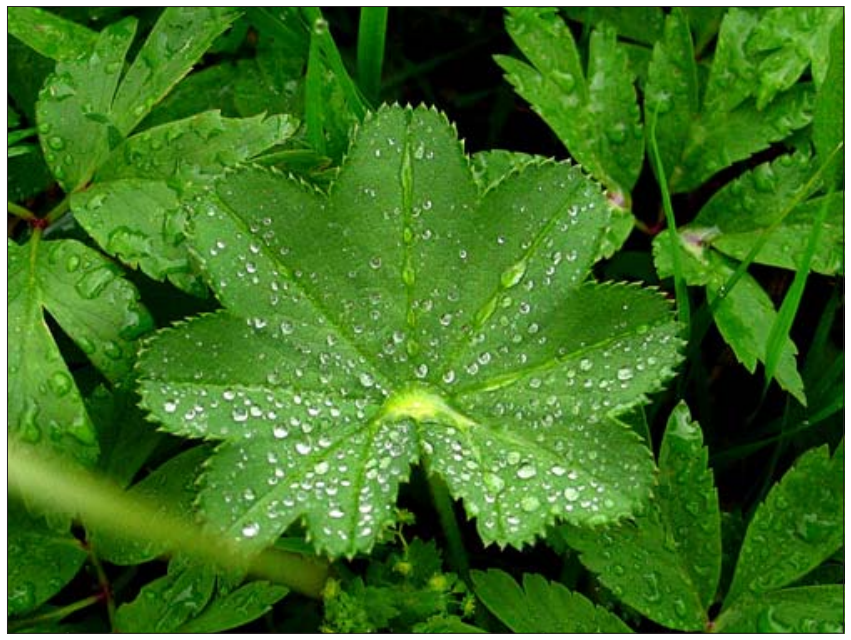

Illustratsioon 17. Harilik kortsleht (Alchemilla vulgaris L.). http://img-2005-05.photosight.ru/22/872425.jpg

guja" (Sverdlovski oblasti Turinskaja Sloboda rajoon), "kristuse kastega pestakse silmi, onnistatud rohi (Sverdlovski oblasti Turinski rajoon; Konovalova 2000: 201).

\section{Kokkuvõtteks}

Toodud näited demonstreerivad taimede objektiivsete reaalsete tunnuste olulisust sümbolistliku kujundi tekkimisel. Et tunnuseid interpreteerida, on vaja vaadata leksilist, folkloorset ja mütoloogilist andmestikku, mida ei saa näidata üksnes rahvameditsiini andmete analüüsimise abil. Ettekujutus taimedest moodustub olulisel määral nende iseloomulike tunnuste alusel, mis määravad ka taimede kasutamise rituaalses praktikas ja igapäevaelus. Kuid tunnus võib esineda ka võimalike ümberkodeerimiste alusena (taime nime moodustamine teistes rahvakultuuri koodide terminites) ainult aktiivse vahendaja - loomuliku keele - rollis (Baiburin \& Levinton 1983: 28-29). Fütonüüm seostub sõnade ja reaaliatega, moodustades teiseseid assotsiatsioone. Selliselt kajastavad taimede nimetused nende reaalseid omadusi, kuid teevad seda läbi rahvakultuuri kohaliku versiooni prisma.

Et luua rahvakultuuri teiste koodide seas ka rahvabotaanika fond, kasutatakse piiblikoodi. Selle raames on olulised seosed rahvapiibli tekstidega, sealhulgas apokriivadega, aga ka keeleline klišee ja ikonograafiline traditsioon. 
Artiklis analüüsitud fütonüüme ja etioloogilisi legende kasutatakse traditsioonis kui instrumenti, selgitamaks, miks valiti teatud haiguse ravimiseks üks või teine taim. Võib öelda, et rahvakultuuris - vähemalt kaudselt - vaadeldakse haigust kui inimese anomaalset seisundit, kuid seda käsitletakse ka ümbritseva maailma objektide tekke mütoloogilisele ajale lähedase olukorrana, ja haige paigutatakse mütoloogilisse ruumi, kus ta kasutab ravimitena taimi, mis tekkisid tänu kristliku mütoloogia tegelastele; see kordub iga uue patsiendi ravimise käigus alati uuesti.

\section{Tõlkinud Asta Niinemets}

\section{Kommentaarid}

1 Artiklis analüüsitavad taimekasutusprintsiibid olid lisaks rahvameditsiinile aktuaalsed ka teistes rahvakultuuri valdkondades. Nii arvati, et kultuurtaimede juurdumist ja kasvu mõjutab istutamispäev. Näiteks kapsast, "mida aianduses seostatakse järjekindlalt peaga üldiselt ja eriti püha Johannese peaga", istutati Ristija Johannese pea leidmise päeval (25. mail/7. juunil). Pea assotsieerub mitte üksnes kapsapeaga, vaid ka teiste ümmarguse kujuga köögiviljadega, sellepärast olid idaslaavlastel levinud "keelud minna aeda ja lõigata kapsast, tõmmata rediseid ja üldse mis tahes ümmargusi juurvilju, et see tegevus ei meenutaks Ristija Johannese pea mahalõikamist”. Et kapsapea kasvaks suureks ja tugevaks, pidid naised mõlema käega võtma peast kinni (Brest), siduma pea ümber rätiku (Kursk). Sõnaliselt võis istutamise saateks öelda: "Kasva, kapsas, minu pea suuruseks" (Moroz 2000: 133-134, 143).

2 Viide urbepäevale.

${ }^{3}$ Kuivõrd Balkanil on moslemi ja kristlik kultuur tihedasti põimunud, kannab üks ja sama taim nime jumalaema käsi ja fatima käsi: "Sünnitaja joob tõmmist [---] nii nagu avaneb see rohi, meenutades kujult kätt, avaneb ka tema keha” (SD 3: 596).

4 Vanaema Solomonida - mütoloogiline ämmamoor, keda sageli mainitakse posimisel raske sünnituse korral. Kuigi otsesed viited sellele puuduvad, sunnib see fütonüüm oletama, et jumala- või kuradikäppa võidi kasutada ka rahvameditsiini sünnitusabis. Kuid ka Solomonida nimeta mõjub käe semantika endena, suutlikkus avaneda on sünnitusel oluline, millest oli ka eespool juttu. 


\section{Arhiiviallikad}

EU Tšernovits = EУ-Черновиц-99 = Материалы экспедиции Европейского университета в Санкт-Петербурге в с. Старые Бросковцы Сторожинецкого р-на Черновицкой обл. 1999 г. - Sankt Peterburi Euroopa Ülikooli välitööd Starõje Broskovitsõ Storožinetski rajoonis Tšernovitski oblastisse. Materjalid on hoiul Sankt Peterburis asuva Euroopa Ülikooli arhiivis.

\section{Kirjandus}

Annenkov 1876 = Анненков, Николай. Ботанический словарь. Санкт Петербург: Типографія Императорской Академіи Наукъ.

Arandarenko 1849 = Арандаренко, Николай. Записки о Полтавской губернии Николая Арандаренка, составленные в 1846 году. В 3-х ч. Ч. 2. Полтава: В Типографии Губернского Правления..

Arjanova 2007 = Арьянова, Валентина. Словарь фитонимов Среднего Приобья 2. В 3-х т. Томск: Издательство Томского государственного педагогического университета.

Afanasjev 1994 = Афанасьев, Александр. Поэтические воззрения славян на природу. В 3 т. Москва: Индрик. [1865-1869. aasta väljaande ümbertrükk.]

Ahtarov 1939 = Ахтаров, Борис. Материал за български ботаничен речник. София: Придворна печатница.

Baiburin \& Levinton 1983 = Байбурин, Альберт \& Левинтон, Георгий. О соотношении фольклорных и этнографических фактов. Acta Ethnographica Academiae Scientiarium Hungaricae 32. (1-4), lk 3-31.

Brõsina \& Kudrjašova 2003 = Брысина, Евгения \& Кудряшова, Римма. Составные наименования растений в донских говорах. Лексический атлас русских народных говоров. Материалы и исследования. 2000. Санкт-Петербург: Наука, lk 269-274.

Budziszewska, Wanda 1993. Z goralskich nazw roślin (na tle porownawczym). Kuźnicka, Barbara (toim). Historia lekow naturalnych IV. Warszawa: Instytut Historii Nauki PAN, lk 87-97.

Bulašov 1909 = Булашев, Георгий. Украинский народ в своих легендах и религиозных воззрениях и верованиях. Вып. 1. Космогонические украинские народные воззрения и верования. Киев: Типография университета св. Владимира.

Dmitriev 1869 = Дмитриев, Михаил. Собрание песен, сказок, обрядов и обычаев крестьян Северо-Западного края. Вильна: Печатня А. Г. Сыркина.

Džordževitš 1958 = Ђорђевић, Тихомир. Природа у веровању и предању нашега народа 1. Српски етнографски зборник LXXI. Београд:

Fedotov 1991 = Федотов, Георгий. Стихи духовные. Русская народная вера по духовным стихам. Москва: Гнозис. 
Gantšarõk 1927 = Ганчарык, Міхаіл. Беларускія назовы расьлін 1. Праца Навуковога таварыства па вывученню Беларусі. II. Горы-Горкі: Друкарня і камнядрук Акадэміi, lk 194-216. Беларускія назовы расьлін 2. Праца Навуковога таварыства па вывученню Беларусі. IV. Горкі: Друкарня і камнядрук Акадэміi, lk 1-28.

Grintšenko 1958 = Гринченко, Борис. Словарь украинского языка, собранный редакцией журнала “Киевская старина". Киів: Академия наук УССР.

Henslowa, M. 1976. Z badań nad wiedzą ludową o roślinach. I. Hypericum perforatum L. - Dziurawiec zwyczajny. Slavia Antiqua XXIII, lk 229-251.

Ivanova 2002 = Иванова, Радост. Култура на кризата - криза в културата. София: ИК БАН.

Jakušin 1844 = Якушкин (ilma eesnimeta). Народные сказания о кладах, разбойниках, колдунах и их действиях, записанные в Малоархангельском уезде. Москвитянин 6 (11-12), lk 25-44. Смесь.

Kableškova 2002 = Каблешкова, Райна. Отражение на билките в българските народни вярвания и използването им в народната медицина. Етър. Етноложки изследвания 4. Габрово, lk 95-110.

Kolberg, Oskar 1874. Dziela wszystkie 7. Krakowskie. Cz. 3. Krakow: Polskie Wydaw. Muzyczne (http://www.oskarkolberg.pl/index.php/site/dziela/96 - 21. juuni 2010).

Konovalova 2000 = Коновалова, Надежда. Словарь народных названий растений Урала. Екатеринбург: МРЦ.

Kupala 1861 = Народный праздник Купала, описанный и объясненный ведля сохранившихся преданий и поверий народа. Львов.

Kuznetsova \& Reznikova 1992 = Кузнецова, Мария \& Резникова, Анна. Сказания о лекарственных растениях. Москва: Высш. школа.

Machek, Václav 1954. Česka a slovenska imena rostlin. Praha.

Makowiecki, Stefan 1936. Slownik botaniczny lacińsko-maloruski. Krakow: Nakł. Polskiej Akademii Umiejętności.

Mandelštam 1882 = Мандельштам, Иосиф. Опыт объяснения обычаев (индоевропейских народов) созданных под влиянием мифа I. Санкт-Петербург: Типо-Литография А.Е. Ландау.

Marinov 2003 = Маринов, Димитър. Народна вяра. Нзбрани произведения в 5 тома I: 1. София: Изток-Запад.

Markevitš 1860 = Маркевич, Николай. Обычаи, поверья, кухня и напитки малороссиян. Извлечено из нынешнего народного быта и составлено Николаем Маркевичем. Киев.

Morawski, Z. 1884. Myt roślinny w Polsce i na Rusi. Tarnow: W drukarni Józefa Styrny.

Moroz 2000 = Мороз, Андрей. Народное огородничество у восточных славян как система кодов. Кодови словенских култура 5, lk 131-145.

Petrovitš 1992 = Петровић, Сретен. Културна историја Сврљига 1. Ниш-Сврљиг: Просвета. 
Punase 1987 = По страницам Красной книги. Растения. Популярная энциклопедия справочник. Минск: Изд-во Белорусская советская энциклопедия им. П. Бровки.

Popov 2004 = Попов, Р. Народная этимология и культ святых. Язык культуры: семантика и грамматика. K 80-летию со дня рождения академика Н. И. Толстого (1923-1996). Москва: Индрик, lk 131-137.

Rodionova 2002 = Родионова, Инна. Библейские мотивы в народных названиях растений. Живая старина 2 (34), lk 38-39.

SGRS = СГРС 1 = Матвеев, Александр (toim) 2001. Словарь говоров Русского Севера I, А-Б. Екатеринбург: Издательство Уральского университета (http://starling.rinet.ru/ $\sim$ minlos/Slovar govorov severa/ - 21. juuni 2010).

$\mathrm{SD}=$ СД = Толстой, Николай (toim) 1995, 1999, 2004. Славянские древности. Этнолингвистический словарь в 5 томах. Москва: издательство Международные отношения (http://www.bogoslov.ru/text/885929/index.html - 21. juuni 2010).

Sedakova 2007 = Седакова, Ирина. Балканские мотивы в языке и культуре болгар. Родинный текст. Москва: Индрик.

Sementovski 1845a = Сементовский, Александр. Очерки малороссийской демонологии. Киевские губернские ведомости. Прибавление к № 13, lk 91-93; Прибавление к № 14, lk 98-100; Прибавление к № 15, lk 108-109; Прибавление к № 16, lk 117-118.

Sementovski $1845 \mathrm{~b}$ = Сементовский, Константин. Некоторые народные обычаи и поверья здешней губернии. Полтавские губернские ведомости. Прибавление к № 15 , lk 157-158; Прибавление к № 19, lk 187-189; Прибавление к № 22, lk 213-214; Прибавление к № 24, lk 227-228; Прибавление к № 37 , lk 352-354.

Seweryn, Tadeusz 1946. Ikonografia etnograficzna. Lud 37, lk 277-308; 1947 Lud 38, lk 229-276; 1948-1951 Lud 39, lk 291-354.

SK 1993 = Софийски край. Етнографски и езикови проучвания. София: БАН.

Sofritš $1990=$ Софрић, Павле. Главније биље у народном веровању и предању код нас Срба. Београд: БИГЗ.

Spólnik, Anna 1990. Nazwy polskich roślin do XVIII wieku. Wrocław: Zakład Narodowy im. Ossolińskich.

SRG 2006 = СРГКПАО = Копытов, Николай \& Подюков, Иван \& Черных, Александр. Словарь русских говоров Коми-Пермяцкого округа. Пермь: ПОНИЦАА.

SRNG $(1965-2007)=$ СРНГ $8(1972)=$ Vene murrete sõnaraamat $8=$ Словарь русских народных говоров 8. Ленинград: Наука (http://iling.spb.ru/vocabula/srng/srng.html 21. juuni 2010).

Szot-Radziszewska, Elżbieta 2005. Sekrety zio1. Wiedza ludowa, magia, obrzędy, leczenie. Warszawa: Trio.

Sumtsov 1889 = Сумцов, Николай. Этнографические заметки. Этнографическое обозрение 3, lk 111-133. 
Špis-Ćulum, Marija 1995 = Шпис--уулум, М. Фитонимија југозападне Бачке (коровска флора). Српски дијалектолошки зборник XLI. Београд: Српска академија наука и уметности, lk 397-490.

Šulek, Bogoslav 1879. Jugoslavenski imenik bilja. Zagreb: Dion.

Zibrt, Č. 1896. Z netištěnych zapisků Krolmusovych. Česky lid 6.

Toren 1996 = Торэн, Мария. Русская народная медицина и психотерапия. СанктПетербург: Литера.

Tšaikanovits 1985 = Чајкановић, Веселин. Речник српских народних веровања о билкама. Београд: Srpska književna zadruga.

Tšasovnikova 2003 = Часовникова, Анастасия. Христианские образы растительного мира в народной культуре. Петров крест. Адамова голова. Святая верба. Москва: Индрик.

Ussatševa 2000 = Усачева, Вероника. Мифологические представления славян о происхождении растений. Толстая, Светлана (toim). Славянский и балканский фольклор. Народная демонология. Москва: Индрик, lk 259-302.

Velmezova 2004 = Вельмезова, Екатерина. Чешские заговоры. Исследования и тексты. Москва: Индрик.

Wereńko, F. 1896. Przyczynek do lecznictwa ludowego. Materialy antropologiczno-archeologiczne i etnograficzne I. Krakow: Akademja Umiejętności w Krakowie, lk 99-228.

Wjela, J. 1896. Naše rostlinske mjena z přimjenami. Hórnik Michal (toim). Ćasopis maćicy serbskeje. Lětnik IXL. Zešiwk 2, lk 133-142.

\section{Summary}

\section{"Folk Bible" as the Expounder of Slavic Ethno- medicine related Customs}

\section{Valeria Kolosova}

Key words: ethno-botany, "folk Bible", folklore, folk medicine, Slavonic dialectology

The article demonstrates how, among the Slavs, a given objective feature of a plant becomes an important factor in the selection of plants for use in folk medicine. At the same time, this feature provides remarkably close ties between the plant, folk beliefs about certain biblical personages, and the symptoms of disease. The role of another mediator - natural language - is no less important for connections between different codes of traditional culture. A plant name becomes linked to words and objects, thereby acquiring secondary associations. Thus, traditional culture regards disease not only as a deviation but also as a situation close to the mythological time of world creation, and a patient is placed in the mythological space where he uses, as medicine, the herbs 
which have "appeared" thanks to characters of Christian mythology. The phytonyms and etiological legends, analysed in the article, are used within the tradition as an instrument to ascertain the reason why a specific plant was selected for the treatment of a certain illness. In folk culture, an illness is observed - at least indirectly - as an anomalous state of the human being, however, it is also treated as a situation close to the mythological time of origin of the objects of the surrounding world, and the ailing person is placed in the mythological space wherein he/she would use medicinal plants created thanks to the figures of Christian mythology; this re-occurs again in the treatment of each new patient. 